\title{
THE SIXTH REPUBLIC UNDER ROH TAE WOO: THE GENESIS OF SOUTH KOREAN DEMOCRACY
}

\author{
by Grażyna Strnad
}

\section{INTRODUCTION}

The inauguration of Roh Tae Woo as president of the Sixth Republic of Korea in February 1988 can be considered as a turning point in South Korean political history. The five years of the Roh Tae Woo administration, 1988-1993, contained many of the first steps, albeit sometimes transitionally imperfect, toward democracy and an ultimate return to civilian rule of law, as well as greater political freedoms. According to Samuel P. Huntington, the Korean form of democratization was an example of transplacement, in which the government made concessions and opposition political groups accepted it to avoid mutual catastrophe. Furthermore, a case can be made for the mode of democratic transition in South Korea also being like Donald Share's transition through transaction, Terry Lynn Karl and Philippe C. Schmitter's transition by pact, and Adam Przeworki's democracy with guarantees. ${ }^{1}$

\footnotetext{
1 Hyug Baeg Im, South Korean Democratic Consolidation in Comparative Perspective, in Larry Diamond and Byung-Kook Kim, eds., Consolidating Democracy in South Korea (Boulder and London: Lynne Rienner Publishers, 2000), p. 25.
} 
Roh Tae Woo represented the moderate faction within the military ruling bloc which acknowledged the widely perceived lack of legitimacy of the Fifth Republic and the Chun Doo Hwan administration; the perception was in large measure due to ruthless seizure of power in 1979 and 1980 by the New Military, and culminating with the brutal putdown of the Kwangju Uprising in May of 1980, ${ }^{2}$ which is sometimes termed as the Kwangju Minjung (masses) Resistance, or the Kwangju Massacre. The Roh administration recognized the strength of the opposition which culminated with the June Uprising of 1987, also known as the 10 June Democratization Movement, and the changing national and international political environmental, the time for an authoritarian system was over in South Korea. The break with the past military rule was a very significant moment.

The South Korean transition to democracy was relatively peaceful. It has been the first peaceful transfer of power in South Korea since 1960 with the brief inception of the Second Republic after Rhee Syngman was forced from office after 12 years of being president. Former South Korea presidents Park Chung Hee and Chun Doo Hwan had come to power through military coups in 1961 and 1980. Roh Tae Woo received a modest mandate receiving only 36.6 percent of the popular vote. Ultimately, it was ironic that Roh was nation's first democratically elected chief executive in years. Roh Tae Woo had been former army general, was a protégé of Chun Doo Hwan, and had been a participant in the 12.12 Incident or Coup, as well as having been a representative of the authoritarian regime of the Fifth Republic. Roh's victory was the consequence of the opposition being unable to run a single candidate; Kim Young Sam, Kim Dae Jung and Kim Jong Pil all ran for president in December of $1987 .{ }^{3}$

\footnotetext{
2 Namhee Lee, The Making of Minjung (Ithaca and London: Cornell University Press, 2007), pp. 44-48. Currently, some South Korean scholars refer to the Fifth Republic as having "original sin" or a "birth defect," because of the ruthless seizure of power in general, and the suppression of the Kwangju Minjung Resistance, in particular.

3 David I. Steinberg, Korean Democracy Today, in Christopher J. Sigur, ed., Democracy in Korea: The Roh Tae-woo Years (New York: Carnegie Council on Ethics and International Affairs), pp. 48-49.
} 
It can be argued that Korean democratic transition fits the elite ascendant form of democracy as theorized by Terry Lynn Karl, who defines democracy as: "A set of institutions that permits the entire adult population to act as citizens by choosing their leading decision-makers in competitive, fair, and regularly scheduled elections which are held in the context of the rule of law, guarantees of political freedom, and limited military prerogatives." Based on this definition, democracy is a political concept with four dimensions: (1) contestation over policy and competition for office; (2) participation of the citizenry through partisan, associational, and other forms of collective action; (3) accountability of government to the citizens through mechanisms of representation and the rule of law; and (4) civilian control over the military. ${ }^{4}$

\section{PRO-DEMOCRATIC (JUNE) DECLARATION}

Roh Tae Woo, the presidential candidate for the Democratic Justice Party (DJP) ended the domestic political crisis of 1987, sometimes called the June Uprising, with an eight-point declaration, or 29 June Declaration, in which he expressed what appeared to be his own political will to begin the democratization process with a peaceful transfer of power through a direct presidential election. The eight points of the 29 June Declaration were: (1) rapid constitutional revision for direct presidential election; (2) new presidential election laws guaranteeing fairness; (3) restoration of civil rights for blacklisted political leaders; (4) legal guarantees and protection of human rights; (5) withdrawal of the Press Law, thus creating a free press; (6) restoration of local political autonomy, to include campus autonomy; (7) guarantees of free political party activities; and (8) national campaign against corruption, as well as social reform. ${ }^{5}$ According to Chun Doo Hwan's memoirs, the 29 June Declaration was his idea to diffuse the

${ }^{4}$ Extracts from Terry Lynn Karl, Dilemmas of Democratization in Latin America, “Comparative Politics", Vol. 23, No. 1, October 1990, pp. 1-23, at http://www.chsbs. cmich.edu/fattah/sum/Karl.doc (Retrieved on 28 December 2009).

5 Carl J. Saxer, From Transition to Power Alternation, Democracy in South Korea, 1987-1997 (New York and London: Routledge, 2002), p. 62. 
gaining momentum and street protests of the opposition demanding a direct presidential election. Chun wrote that the declaration would make candidate Roh into a hero, and that he had surmised that the opposition would not be able to agree on a single candidate, thus guaranteeing an election victory for Roh Tae Woo and the DJP. ${ }^{6}$

Cynically, it can be said that the 29 June Declaration was a calculated act of desperation and cunning, a pragmatic acceptance of newly developing centers of power. On the other hand, the 29 June Declaration by Roh Tae Woo was also an acceptance of pluralism that had been built of over the previous half-decade in South Korea. In the mid-1960s, Gregory Henderson wrote about Korea: Politics of the Vortex, in which he theorized on a centralizing nature of power in traditional, colonial and modern Korea. It had been significant that in Korean political history tended to be centripedal, attempting to reconstitute power in a vortex toward the center rather that from the center.7 David I. Steinberg suggests that this vortex collapsed with the June Uprising and the following June Declaration. The Henderson model has been a debatable fixture of Korean political analysis and thought since the publication of Korea: Politics of the Vortex in 1965. Some scholars can find ample evidence that the socalled vortex survived the first phases of democratic transition, while other reject the existence of the vortex completely. In any event, pluralism was not simply an important undercurrent during the spring and summer of 1987; it was manifest in middle-aged and middle class citizens joining the usual protesting students on the streets of South Korean cities. Once the June Declaration was made, these same middle class citizens, having realized their collective aspiration for democratic institutions, generally withdrew from the active political discourse. ${ }^{8}$

\footnotetext{
6 From Kim Song-ik, Chŏn Tu-hwan yuksŏng chungŏn [The Spoken Testimonies of Chun Doo Hwan] (Seoul: Ilbo-sa, 1992), p. 429, cited in John Kie-chiang Oh, Korean Politics, The Quest for Democratization and Economic Development (Ithaca and London: Cornell University Press, 1999), pp. 62-63.

7 Gregory Henderson, Korea: Politics of the Vortex (Cambridge: Harvard University Press, 1965), pp. 13-35.

8 David I. Steinberg, op.cit., p. 75.
} 


\section{PRESIDENTIAL ELECTION}

By most accounts, personalization and regionalism played decisive roles in the 1987 presidential election. The voting alignment and distribution in the election was characteristic of modern historical South Korean voter patterns and preferences. In general, voter support of candidates was based an urban-rural dichotomy, and very pronounced regional cleavages. The election gave Roh Tae Woo of the DJP 36.6 percent, with a plurality of 2 million votes; Kim Young Sam of the Reunification Democratic Party (RDP) received 28 percent; Kim Dae Jung of the Party for Peace and Democracy (PPD) received 27 percent; and Kim Jong Pil of the New Democratic Republican Party (NDRP) received 8 percent. ${ }^{9}$

Retrospectively, however, a collective concern for national security which continued to grow and shift the perception and concerns for the South Korea electorate throughout the fall of 1987 played an important role. In late November 1987, a Korean Airlines flight from Baghdad to Seoul exploded killing all 115 aboard. The act was proven to be that of North Korean agents. ${ }^{10}$ This terrorist act which occurred two weeks prior to the election, coupled with growing revelations since 1983 regarding the expansion of North Korean military ground forces, clearly influenced older members of the electorate who had memories of the Korean War. In the final analysis, Roh Tae Woo's military experience was a plus in the minds of many voters.

In addition to security concerns, the reasons why Roh Tae Woo won, despite his having participated in the 12.12 Incident in 1980, and his being associated with Chun Doo Hwan and the previous unpopular regime, were the following: (1) each candidate had a distinct regional power base, but had no national constituency; (2) the ruling party had financial and organizational advantages with which the opposition parties could not compete. Estimates are that the DJP spent between $\$ 300$ million to $\$ 1$ billion on the election; (3) there were many Korean voters whose votes

9 Young-hwan Kihl, South Korea's Search for a New Order, in Ilpyong J. Kim and Young-hwan Kihl, eds., Political Change in South Korea (New York: Paragon House, 1988), pp. 15-19.

10 Carl. J. Saxer, op.cit., p. 74. 
were purchased by the government. Rural votes were bought with such gifts as rice, and government employees received small cash payments; (4) opposition candidates underestimated the achievements of the Park Chung Hee and Chun Doo Hwan governments. A number of voters clearly remembered the Korea War and the following economic hardships of the 1950s and the 1960s; (5) the ruling party assessed a credible scenario in which the two Kims, Kim Young Sam and Kim Dae Jung, would run against each other; (6) as a result of the failure of the opposition to run a single candidate the two Kims lost perceived moral high ground; (7) the election was effectively manipulated by the government through manipulation of the two major television networks, Korean Broadcasting System (KBS), and Munhwa Broadcasting Corporation (MBC). Manipulation often took the form of the disproportionate broadcasting of positive segments about Roh Tae Woo, and focused negative segments about the opposition, particularly on the discord between the two Kims;"11 (8) Roh presented himself as a bot'ong saram (ordinary person), which was deliberate way of contrasting his perceived low-key and soft-spoken leadership style to the generally unpopular former president Chun who was often characterized as crass and arrogant; South Koreans received this marketing strategy quite favorably.12

\section{PARLIAMENTARY ELECTIONS}

The parliamentary election of 1988, held on 26 April, resulted in the DJP receiving only 34 percent of the popular vote, which translated into 87 of the 224 contested single-member district parliamentary seats. Additionally, the DJP gained 38 of the 75 at-large sears under the new proportional representation system, giving the DJP a total of 125 of the 299 seats

11 Okonogi Masao, South Korea's Experiment in Democracy, in James Cotton, ed., Korea under Roh Tae-woo: Democratization, Northern Policy, and Inter-Korean Relations (Canberra: Allen \& Unwin, 1993), pp. 15-17, and Manwoo Lee, The Odyssey of Korean Democracy, Korean Politics, 1987-1990 (New York: Praeger, 1990), pp. 46-52, \& pp. 73-74.

12 Choong Nam Kim, The Korean Presidents, Leadership for Nation Building (Norwalk: EastBridge, 2007), p. 222. 
in the South Korean Parliament. ${ }^{13}$ The reasons for the poor performance of the DJP were: (1) a post-authoritarian revulsion against centralized power translating into the desire of voters to limit the ruling party's power; (2) continuous new stories about Fifth Republic scandals and widespread corruption in the South Korean media; (3) the DJP failed to attract young and well-educated voters; (4) the DJP was embarrassed by media coverage of a number of campaign blunders and corruption; and finally, (5) the DJP's failure was, in part, due to strong regional sentiments. ${ }^{14}$

The 1988 parliamentary election was a continuation of the negotiated settlements between the government and the opposition forces. The Roh administration was caught between the pressure from increasingly assertive groups and personalities, and from elements inside the DJP. Roh faced enormous pressure from the three opposition parties, and the public, to investigate the corruption and crimes of the Fifth Republic. The two leading opposition parties in particular, the PPD and the RDP, were mandated by the April election to investigate the Fifth Republic; the parties needed a cooperation of the government, and the Roh administration needed to cooperate or be accused of a cover-up.

The post-election period was characterized by the phenomenon of yoso-yadae (government-minority, opposition-majority). The government, therefore, not being able to control the parliament, much less lead the legislative agenda, was exacerbated by the ongoing Fifth Republic hearings. In a purely political sense, however, the 1988 parliamentary election resulted in a liberalization of the political process coupled with a greater tolerance for the opposition; the government had to engage in political compromise and cooperation. ${ }^{15}$ This process, however, resulted in

13 Hong-nack Kim, The 1988 Parliamentary Election in South Korea, in James Cotton, ed., Korea under Roh Tae-woo: Democratization, Northern Policy, and Inter-Korean Relations (Canberra: Allen \& Unwin, 1993), p. 117.

14 Jin Park and James Cotton, Political Change in South Korea: The Challenge of the Conservative Alliance, in James Cotton, ed., Korea under Roh Tae-woo: Democratization, Northern Policy, and Inter-Korean Relations (Canberra: Allen \& Unwin, 1993), pp. 139-140.

15 Dalchoong Kim, Democracy under the Sixth Republic, in Christopher J. Sigur, ed., Democracy in Korea: The Roh Tae-woo Years (New York: Carnegie Council on Ethics and International Affairs, 1993), p. 33, and Yong-ho Kim, Party Politics and the Process of 
a political deadlock. The deadlock over the next two years between the executive and legislative branches would result in a three-party merger in early 1990, which was quite typologically consistent with Karl's elite ascendant democratic transition. ${ }^{16}$

\section{DIRECTION OF DEMOCRATIC TRANSITION}

\section{THE NEW CONSTITUTION}

The new constitution was first drafted on 18 September 1987, and the parliament approved it on 12 October 1987. On 28 October 1987, the new constitution was ratified by 93 percent of the voters in a national referendum. In creating the new constitution of the Sixth Republic, the DJP and the opposition agreed to strengthen the power of the national assembly, which was weak during the Fifth Republic. Under the new constitution, the national assembly regained all of the powers it had lost under the Park and Chun regimes. The new legislative branch had the power to legislate, approve the national budget, investigate misconduct of government officials, audit government agency expenditures, adopt a vote of no confidence against the prime minister and cabinet members, and impeach executive and judicial officials by a simply majority vote, and the president by a twothirds vote. By majority vote, the National Assembly could suspend martial law proclaimed by the president. Unlike the situation in the Fourth and Fifth Republics, the president had no power to dissolve the national assembly. ${ }^{17}$

The new constitution was not based on the principles of parliamentary democracy, which some theorists of democratic consolidation believe contributed to the stability and accountability of democratic regimes,

Democratization in Korea, in Doh-chull Shin, Myeong-han Zoh, and Myung Chey, eds., Korea in the Global Wave of Democratization (Seoul: Seoul National University Press, 1994), pp. 183-184.

16 Yong-ho Kim, op.cit., pp. 180-181.

17 Hong-nack Kim, op.cit., p. 111. 
instead, it was premised primarily on the principles of presidential democracy, specifically, the separation of powers and checks and balances among the various branches of government. ${ }^{18}$ The constitution of the Republic of Korea, therefore, reflects divisions of power, first between the president and the prime minister, and second between the executive and legislative branches of government, establishing what some suggest is a form of semipresidentialism called a president-parliamentary by Matthew Soberg Shugart and John Carey. Giovanni Sartori suggests the existence of a dualauthority system based on the constitution written prior to the Sixth Republic. Debates and nuances aside, Article 66 (4) clearly established the office of the presidency in the Republic of Korea as the primary center of political power, and this continues to be the case in the current political reality of South Korea. ${ }^{19}$

Importantly, the creation of the constitution prior to the Sixth Republic was, in fact, a collaborative revision between the government and opposition of the 1980 constitution. In this sense, the 1987 constitution was seen by many Korean legal scholars as having more legitimacy than earlier versions. The establishment of a direct popular vote of the president and limiting the president to one term was central. The priority of constitutional revision in South Koreas as relation to democratic transition was the ending of public disaffection for, and distrust of the legitimacy of the constitution and the government. ${ }^{20}$

18 Doh-chull Shin, Mass Politics and Culture in Democratizing Korea (Cambridge: Cambridge University Press, 1999, p. 4.

19 From Matthew Soberg Shugart and John Carey, Presidents and Assemblies: Constitutional Design and Electoral Dynamics (Cambridge: Cambridge University Press, 1992), pp. 18-27, and Giovanni Sartori, Comparative Constitutional Engineering: An Inquiry into Structure, Incentives and Outcomes (London: Macmillan Press, 1997), p. 139, cited in Carl. J. Saxer, op.cit., pp. 69-70.

20 Dae-kyu Yoon, New Developmentalism in Korean Constitutionalism: Changes and Prospects, "Pacific Rim Law and Policy Journal", Vol. 4, No. 2, May 1995, pp. 401-402. 


\section{REVISION OF THE PARLIAMENTARY ELECTION LAW}

After the presidential election in December 1987, the government party and the opposition began contentious negotiations to revise the parliamentary election law and to set a date for National Assembly elections. Initially, the DJP wanted to hold the elections in February 1988; the ruling party would benefit from the momentum of its victory in the presidential election and the disarray in the opposition resulting from the continuing and very public disagreements between the RDP led by Kim Young Sam and PPD led by Kim Dae Jung over forming a single opposition party. After a deadlock in the negotiations, the DJP, with a majority in parliament, passed the new election law at two o'clock am on 8 March 1988. ${ }^{21}$

Under the Fifth Republic (1980 to February 1988) two-thirds of the 276 National Assembly members were elected from 92 two-member districts. The remaining one-third (or 92 seats) was elected through a proportional representation system. Two thirds of these proportional representation seats were allotted to the party winning the largest number of district seas, while one third was allocated in proportion to the seats won by the other parties. The system as a whole favored the government party, assuring it a comfortable majority $\mathrm{n}$ the national assembly. The former system was widely regarded as undemocratic and was unpopular among voters. ${ }^{22}$ The new system of 224 single-member districts, and 75 at-large or proportional representation seats was assessed to be fairer by the general public. Despite the improvements in the election law, the proportionality of the National Assembly seats reflected a continuation of the pattern of yŏch'on yado (government party supported in rural areas, opposition supported, in the urban areas), though not as well-defined in the 1985 parliamentary election, for example. ${ }^{23}$ This underscores Terry Lynn Karl's warning about electoral fallacy: that is, competitive elections

\footnotetext{
21 Hong-nack Kim, op.cit., p. 110

22 Ibidem, pp. 110-113.

23 Carl. J. Saxer, op.cit., pp. 79-80.
} 
alone should not be regarded as a sufficient condition for democracy. In some instances, institutional or political reform must be implemented to make the elections meaningful. ${ }^{24}$

\section{LIQUIDATION OF THE FIFTH REPUBLIC (OGONG CH’OัNGSAN)}

The process of transition from authoritarian rule to democracy necessitated coming to terms with the abuses of power of the Fifth Republic. Prior to Roh being sworn in as the new president, the government established a Committee to Further Democratic Consensus in order to deal with abuses of the Fifth Republic in general, and the Kwangju Uprising in particular. Regarding Kwangju, the Roh Tae Woo administration's attempts to compensate victims and erect monuments and a memorial hall for those killed or injured proved to be quite insufficient. ${ }^{25}$ The corruption issue in the South Korean parliament caused former president Chun Doo Hwan to relinquish two positions in early April 1988. Chun resigned from the Advisory Council of Elder Statesmen and from the honorary chairmanship of the DJP. The council was controversial because just before Chun had left office on 25 February 1988, he had expanded its authority beyond mere ceremony. Many Koreans suspected that Chun hoped to use the office to exercise behind-the-scenes control over Roh Tae Woo. South Korean citizens were consumed by this idea in November and December of 1988, when after many years, the parliament's power of investigation was restored and televised hearings on the Chun government were launched. ${ }^{26}$

Roh Tae Woo, under pressure from opposition politicians and growing student demonstrations, initiated secret negotiations between all four

\footnotetext{
${ }^{24}$ Larry Diamond and Doh-chull Shin, Introduction: Institutional Reform and Democratic Consolidation in Korea, in Larry Diamond and Doh-chull Shin, eds., Institutional Reform and Democratic Consolidation in Korea (Stanford: Hoover Institution Press, 2000), p. 19.

25 Man-gil Kang, A History of Contemporary Korea (Kent: Global Oriental, 2005), pp. 215-216.

26 Yong-ho Kim, op.cit., p. 185.
} 
major political parties. The negotiations resulted in eleven points, one of which mandated the testimony of former president Chun before the parliament on 31 December 1989.27 The hearings dealt with charges of corruption and repression that had been the subject of rumors and unproven allegation by students, dissidents, and opposition politicians. Numerous revelations came into being regarding Chun Doo Hwan's rise to power and his abuse of power. The hearings revealed much about the 12 December Incident, the Kwangju Uprising, the Samchung Reeducation Camp, a scheme to prolong Chun's rule, and the misuse of political funds. The hearings resulted in arrest and jail in February 1989 of 47 people closely associated with the Chun government. Among those arrested where included Chun's two brothers, his wife's brother, and other relatives and associates. ${ }^{28}$

\section{LIBERALIZATION AND FREEDOM OF THE PRESS}

The 29 June Declaration and reforms under the Roh administration greatly expanded the press in South Korea. Prior to the declaration there were 32 daily newspapers, 201 weeklies, and 1.203 monthly magazines or journals published in the entire nation. By June 1992, these numbers increased to 117 daily newspapers, 1,561 weeklies, and 2,745 monthly magazines and newspapers. ${ }^{29}$ During the Roh Tae Woo administration a variety of liberalizing reforms were adopted to safeguard political rights and civil liberties among individual citizens as well as civic and political associations. For example, new laws were enacted in March 1989 further protecting the rights of assembly and free speech, particularly in the context of political protests. The government liberalized restrictions of foreign travel and bans on the publication and possession of works on communism and North Korea. Of all the transitional reforms, none was

27 Carl. J. Saxer, op.cit., p. 96.

28 Yong-ho Kim, op.cit., pp. 185-186.

29 Seung-Mock Yang, Political Democratization and the New Media, in Larry Diamond and Doh-chull Shin, eds., Institutional Reform and Democratic Consolidation in Korea (Stanford: Hoover Institution Press, 2000), p. 157. 
more contentious that that of freedom of the press. The Basic Press Act of 1980 was repealed in November 1987, the Bureau of Information Policy abolished, and numerous press restrictions in the South Korean Criminal Code and National Security Law were either deleted or revised. The Roh administration attempted to make freedom of the press de facto by abandoning various extralegal practices of controlling the new media such as the issuing of official guidelines and press cards. ${ }^{30}$

After the 29 June Declaration, the lame-duck Chun administration tried to control the press, resulting in the Shin dong-a Crisis in September 1987. The Shin dong-a (New East Asia) was a monthly periodical published by the Dong-a Ilbo, a South Korean daily newspaper. The government requested that an article being prepared for press which was critical of the Chun administration be omitted. The editors of the Shin Dong-a refused to comply with the government demand. The National Security Planning Agency (NSPA) (Kukkaanjonkuwoik-bu) attempted to intimidate the magazine's management and editorial board. The development attracted national scrutiny because it was the fist test of the sincerity of the ruling party's vow for democratization. Opposition politicians, university students, the press, and indeed, the vast majority of citizens, supported the Shin Dong-a. Under public pressure, the government apologized for the "unnecessary dispute and inconvenience," and repealed its restriction on the publication of the periodical. ${ }^{31}$ Less than a year later on 6 August 1988, journalist and editor, O Hong-gun, who had written an article highly critical of the military's influence on South Korean politics, was stabbed with bayonets by agents of the Army Intelligence Command (AIC). A number of high-ranking officers attempted to conceal the military's part and many were placed under arrest on 30 August 1988. ${ }^{32}$ The resolution of the Shin Dong-a Crisis and the arrest and indictment of military officers involved in an attempted cover-up of the stabbing of the journalist

30 Ibidem, p. 156; also Larry Diamond and Doh-chull Shin, op.cit., p. 8.

31 Jae-youl Kim, Democratization in South Korea, in James Cotton, ed., Korea under Roh Tae-woo: Democratization, Northern Policy, and Inter-Korean Relations (Canberra: Allen \& Unwin, 1993), pp. 47-49.

32 Bruce Cumings, Korea's Place in the Sun. A Modern History (New York and London: W.W. Norton \& Company, 1997), p. 390, and Saxer, op.cit., pp. 123-125. 
signaled the challenges of dismantling the intelligence and security structures which had for nearly forty years supported authoritarian regimes.

\section{LOCAL AUTONOMY AND LOCAL ELECTIONS}

In edition to the participatory reform of direct election of the president, the other major institutional reform in the process of democratic transition promised by Roh Tae Woo in his 29 June Declaration was local autonomy. The DJP was reluctant prior to 1990 to create a local autonomy system because of concerns about regionalism and the need for more funding for local elections. After the three-party merger, however, in early 1990, the new majority party, the Democratic Liberal Party (DLP) and Kim Dae Jung's newly organized party, the Party for Peace and Democracy (PPD), engaged in numerous discussions on the topic. A parliamentary subcommittee on local autonomy allocated representational seats for cities, counties. Under this system, districts with 300,000 or fewer in population would have three seats, with one additional seat for every additional 200,000 inhabitants over 300,000. The nation was divided into 297 local assembly districts, with a total of 848 assembly seats. ${ }^{33}$

Elections for local representation were held on 26 March 1991 and again on 20 June 1991. Eligible voter turn-out in March was 55 percent with the DLP winning 49.8 percent of the 4,304 local seats, and the main opposition party, the PPD, won 18.8 percent. Independents accounted for 32.2 percent, though more than half were actually pro-DLP. In the June election, eligible voter turn-out was only 58.8 percent. The DLP won 564 of the 866 local councilor seats in the six major cities and the nine provinces. ${ }^{34}$ The new expansion of local autonomy through the local elections of 1991 did not grant fiscal and administrative powers to the local assemblies. Seong Kyoung-ryung has argued that this is evidence of a "strong tradition of statism and centralism" in Korea, and that the attempts toward

33 Robert E. Bedelski, The Transformation of South Korea: Reform and Reconstruction in the Sixth Republic under Roh Tae-woo (New York: Routledge, 1994), pp. 105-107.

34 Ibidem, pp. 48-52, and Carl J. Saxer, op.cit., p. 102. 
local autonomy have been flawed both legally and in terms of political culture. Seong concludes that the local autonomy system is "basically a variant of authoritarian central control with a democratic façade." ${ }^{35}$

\section{NORTHERN POLICY (NORDPOLITIK) AND THE 7 JULY DECLARATION}

The northern policy of the Roh administration, hailed by many at the time as superb policy reform, and evaluated by historians as one of Roh Tae Woo's most substantial achievements, needs to be evaluated with numerous domestic and strategic contextual points in mind: (1) the democratic transition strengthened South Korea's alliances and relationships with democratic nations, particularly the United States; (2) democratization accelerated the establishment of relations between Seoul and former socialist nations emerging from the what had been the Iron Curtain. South Korea calculated its economic success might be emulated by these nations; (3) South Korea's democratization enhanced dialogue with North Korea. North Korea anticipated increased economic ties with South Korea, much in the same way South Korea and China had begun to expand economic exchanges since the mid-1980s ${ }^{36}$; (4) by 1988, Sino-South Korean trade was at $\$ 3.1$ billion dollars a year, 84 percent of South Korea's trade with Communist countries. The trend toward increased integrated economic activity in the region was unmistakable by the time Roh was sworn into office ${ }^{37}$; (5) the Northern policy was formulated as a break with the foreign policy of former authoritarian regimes, enhancing legitimacy of the Sixth Republic; (6) the liberal travel policies were assessed to be a gradual remedy for South Korean radicalism by allowing South Koreans

\footnotetext{
35 Kyoung-ryung Seong, Delayed Decentralization and Incomplete Democratic Consolidation, in Larry Diamond and Doh-chull Shin, eds., Institutional Reform and Democratic Consolidation in Korea (Stanford: Hoover Institution Press, 2000), p. 132.

36 Young-whan Kihl, Democratization and Foreign Policy, in James Cotton, ed., Politics and Policy in the New Korean State: From Roh Tae-woo to Kim Young-sam (New York: St. Martin's Press, 1995), p. 126.

37 Choong Nam Kim, op.cit., pp. 242-243.
} 
to travel to Soviet Union and East European countries to observe the failures of socialism. ${ }^{38}$

In the summer of 1988, the opposition parties, attempting to implement the aspirations of the people, were pressuring the government to normalize relations with North Korea. This was the first major challenge the Roh government confronted; that is, the domestic politicization of inter-Korean relations. In South Korean society in the late-1980s, there were growing demands for national reconciliation and reunification. The public demanded that the government allow more accurate information about North Korean and had been increasingly rejecting the promotion of images of North Korea as the enemy. The Roh administration immediately began making information about the North more available to the general public. ${ }^{39}$ The government rushed to dilute anticommunist education and began promoting unification education, faced with the challenge from the left, the Roh regime desired to impress upon the public its sincerity about reunification and democratization, and began to devise a policy of gradual policy toward normalization of relations between the two Koreas..$^{40}$ Additionally, leaders of the DJP surmised that ownership of the issue of normalization and unification would diminish a source of passionate support which had been almost exclusively in the hands of the opposition. The potential problems of numerous political elements and parties playing a role in the Northern Policy was solved by the August 1990 passing of the South-North Cooperation and Exchange Law, also known as the Ch'angkudan il hwaron (one-channel policy), ${ }^{41}$ which allowed the government control of national policies pertaining to increased engagement with North Korea.

38 Young-whan Kihl, op.cit., p. 126.

39 This was likely not a particularly tortured decision. South Korea had economically surpassed North Korea since the early 1970s, and the North had mounted enormous foreign debt through continued economic mismanagement of its autarkic system and a substantial military expansion. The South Korean government was confident that a new openness to things North Korean would, on balance, be a positive domestic strategy.

40 Manwoo Lee, op.cit., pp. 107-108, and Mangil Kang, op.cit., p. 260.

41 Carl. J. Saxer., op.cit., p. 126. 
In general, President Roh surprised the nation with his 7 July Declaration. The declaration constituted a major policy reversal. The declaration had six proposals: (1) active cooperation between the two Koreas, and a lifting of many travel restrictions; (2) an exchange of letters and visits by separated families; (3) a declaration of intent to expand North and South trade; (4) balanced, developed and an increasing exchange of non-military goods with more nations; (5) cooperation in foreign affairs for the good of the nation; and (6) help the North improve relations with capitalist nations, and for the South to improve its relations with socialist nations. Perhaps most importantly, the declaration was a signal to the international community that South Korea no longer officially perceived the North as a threat to the South, though both South Korean and United States military analysts were concerned that North Korea had been continuing to buildup its conventional ground forces and unconventional warfare forces since the 1970s. ${ }^{42}$ The Roh government launched the Northern Policy as the 1988 Seoul Olympics approached. Roh insisted that nations' participation in the games would help removed East-West barriers, and bring about a new era of international reconciliation and cooperation..$^{43}$ The Northern Policy brought pressure upon North Korea to resume a dialogue with South Korea, which led to the 1991 signing of non-aggression and reconciliation pact between the two Koreas. ${ }^{44}$

\section{CIVILIAN CONTROL OF THE MILITARY}

Roh Tae Woo utilized the public embarrassment of Chun Doo Hwan and his family to dissuade military leaders from association with the former president, though there was still much support of and even loyalty to Chun. In March 1988, however, these charges had gained popular momentum. After Roh Tae Woo discerned that was no indication of

42 Taik-young Hamm, Arming the Two Koreas, State, Capital and Military Power (London and New York: Routledge, 1999, pp. 79-85, and Adrian Buzo, The Guerilla Dynasty (London and New York: I.B. Tauris Publishers, 1999), pp. 96-97.

43 Mangil Kang, op.cit., pp. 260-261, and Manwoo Lee, op.cit., pp. 107-108.

44 Carl J. Saxer, op.cit., p. 124 
a counter-reaction by the military to the media attacks against Chun, he began a series of actions to reform the military and establish civilian control over the military: (1) In June 1988, Roh dismissed Army Chief of Staff, General Park Hee Do, a Chun loyalist, for making threatening remarks against Kim Dae Jung, if Kim were ever elected president. Roh replaced Park with General Lee Hong $\mathrm{Ku}$, a moderate and friend of Roh Tae Woo; (2) In a reshuffle of military leadership positions in June and July of 1988, Roh replaced approximately 70 commanders who had intelligence and garrison backgrounds, or who had been promoted during Chun's administration with those who had long-served in front-line units45; (3) Roh got dismissed Lieutenant General Min Pyong Ton who made a 19 March 1989 speech at the graduation ceremony of the Korea Military Academy (KMA), during which Min criticized Roh's Northern Policy, and twice failed to render proper salutes to the president who was at the ceremony; (4) Roh got rid the military of remaining loyalists during much of 1988. In fact, within three months after the "incident of disrespect," Roh replaced more than half of all three-star and four-star generals in the South Korean military, targeting Chun loyalists; (5) President Roh submitted the 8.18 Plan for the restructuring of the military in 1988. The plan was passed by the legislature after the three-party merger and much debate from the opposition in 1990. The plan, which called for modernization of the South Korean military, and increased military spending, proved being popular among military leaders, thus enhancing loyalty to the Roh administration; (6) Roh practiced favoritism in appointments of general officers, with a disproportionate number of appointees form his home province, North Kyŏngsang. The development attracted national attention because it was the first test of the loyalty of officers, like Roh

45 Jung-kwan Cho, Taming the Military to Consolidate Democracy: The South Korean Experience, "Pacific Focus", Vol. XVI, No. 1, Spring 2001, pp. 127 \& 134. The removal of Chun Doo Hwan appointees was not as vindictive as it was a reasonable strategy given the context of history. Chun had, throughout his career, arranged for many choice assignments and promotions of those close to him, usually ahead of Chun himself. There were many officers, especially from Chun's KMA Class Number 11, who were fiercely loyal to the former president, and many of these same officers, were part of the 12.12 Incident in 1979. 
himself, who were graduates of the KMA; in a relatively short time after the appointments were made, voices of protest within the military disappeared. ${ }^{46}$ By 1992, much of the public believed that the South Korean military had, in fact, retreated from its position of playing a central role in the politics of the nation. ${ }^{47}$

\section{ECONOMIC REFORMS}

Responding to political pressures and to win popular support, the Roh administration early on revised its development plans to expand societal safety nets. The key points in 1988 were a national pension plan, a national medical insurance system and the construction of more rental housing units. ${ }^{48}$ The government began financing 50 percent of individual insurance plans from July 1989. By early 1990, businesses with over five employees became entitled to benefits from a national pension plan and an industrial accident insurance system was established in 1991. The government began to issue grants of 3 million won in concessional loans to low-income people to assist in the repair or reconstruction of old housing units. From 1988 to 1992, the government had planned to build two million housing units for urban and low-income workers. ${ }^{49}$ This governmentfinanced program, however, diverted much capital and labor from a weakened manufacturing sector, which saw wages for industrial laborers increase an average of 24 percent a year between 1988 and 1990. The shortages of labor, land and construction materials caused interest rates to soar to 20 percent per annum..$^{50}$

In an efforts to further enhance its political legitimacy and to win popular support, the Roh government introduced drastic measures designed to diffuse the concentrated economic power and influence of the chaebols (business conglomerates). The government, targeting the chaebols

46 Ibidem, 134-136.

47 Dalchoong Kim, op.cit., p. 39.

48 Robert E. Bedelski, op.cit., pp. 117-118.

49 Ibidem, pp. 118-119.

50 Choong Nam Kim, op.cit., pp. 233-234. 
to improve their international competitiveness and reduce their domestic economic power, as well as win more support by responding to the demands related to social programs, enacted the following reforms: (1) In May 1990, the government ordered the country's 49 largest business chaebols to sell off their idle land and real estate holdings within six months. All land not sold by the government deadline was to be transferred to a state-owned development agency at prices set by the government. The government further threatened the chaebols who failed to meet the deadline with being denied commercial bank credit, forced to repay outstanding bank loans immediately, and be subjected to extensive tax audits. The measure was designed primarily to persuade real estate speculation since the chaebols were earning excess profits from real estate speculation; (2) In March 1991, the government required the top 30 chaebols to nominate up to three of their subsidiaries as their "core business," and were encouraged to specialize in these industries. The government offered relaxed restrictions on bank lending. Moreover, the non-core subsidiaries were required to reduce their outstanding bank loans and freeze borrowing at current levels; (3) The Roh government strengthened the legal, administrative and taxation processes designed to detect and prevent cross-investment, cross-subsidization, cross-payment guarantees, illicit concessions, and inheritance of corporate stocks between and among chaebol owners to prevent violations of the monopoly regulation and free trade law. ${ }^{51}$ Ultimately, however, the slow growth of the South Korean economy forces the Roh administration to make concessions to the chaebols. The formation of the Unification People's Party (UPP) by Hyundai President Chung Ju-yŏng and the running of UPP candidates in the 1992 parliamentary and presidential elections, constituted more than a symbolic challenge to political parties in the electoral process underscored the potential power of the chaebols, a reality of South Korea that would continue to be negotiated throughout the democratic consolidation process in presidential administrations following the Roh Tae Woo administration. ${ }^{52}$

51 Chung-in Moon, Democratization and Globalization as Ideological and Political Foundations of Economic Policy, in Johryn Mo and Chung-in Moon, eds., Democracy and the Korean Economy (Stanford: Hoover Institution Press, 1999), pp. 20-21.

52 Carl J. Saxer, op.cit., pp. 116-121. 
Chun Doo Hwan's economic revitalization of the South Korean economy left the nation with an economic growth rate of 12.9 percent in 1988. Most economic historians acknowledge the difficulties of economic management and democratic transition. By the time of Roh's last year in office, in 1992, economic growth had fallen to 4.7 percent. The reasons for this failure which cost Roh's administration lost of public support were as follows: (1) the Roh administration did not initially place emphasis on the economy, and was hampered by a series of poor appointments and periodic reshuffling of positions related to economic management; (2) the massive public projects attempted by the Roh presidency ran up the nation's debt to $\$ 8.7$ billion dollars by 1991 , and social spending reached 10.2 percent of the national budget that year; (3) Roh seemingly calculated that consolidation of political support was more important than fiscal discipline. An example of this miscalculation was the administration providing farmers with a support package worth $\$ 6$ billion dollars over ten years. This was done to garner political support rather than based on sound fiscal policy since support to farmers clearly strikes a far more symbolic than economically substantive chord with many Koreans because of the nation's agricultural past; and lastly, (4) there was a global recession during the years $1990-1993 .{ }^{53}$

\section{CONCLUSIONS}

Historically, it can be stated that the Roh Tae Woo administration operated within the confines of the constitution. The greatest success of the post-authoritarian Roh Tae Woo administration as the outset of the Sixth Republic was its Nordpolitik policy; South Korea intelligently engaged a rapidly changing region and global political reality. A free press and allowing liberalization of the society was another achievement in the journey toward democratization. The world-wide recession of the early 1990s limited any hope of economic and related social reforms and programs, and was unquestionably the most substantial failure of the new democ-

53 Choong Nam Kim, op.cit., pp. 230-235, and Carl J. Saxer, op.cit., pp. 116-121. 
racy's transition. Curiously, Roh Tae Woo's greatest contribution to attempts at democratic transition may have been his very modest use of his presidential powers during his five-year term. It is, arguably both a matter of a somewhat passive and reactive leadership style and an attempt to avoid association with the Fifth Republic, which created the social and political space sufficient for some of the elemental workings of democratic processes to take hold. It was not particularly an elegant transition, but it was sufficient. Bret I. Billet writes, "As president, Roh encouraged fair elections and the rule of law and respected the National Assembly," referred to in this article as the Parliament. Billet further states that, "In the belief that democracy must take root through the self-regulation of people, he (Roh) exercised maximum restraint in using public power in order to maintain law and order." 54

The three-party merger of 1990 resulted in widespread cynicism among voters who showed their displeasure during the parliamentary election on 24 March 1992 resulting in the newly organized, but still highly factional, government party, the DLP, which had had 215 of the 299 parliamentary seats, to only receive 149 seats, which was one less than a majority. Furthermore, voters displeasure was expressed by an only 70 percent turnout. The main opposition party, Kim Dae Jung's Democratic Party, won 97 seats; the UPP, having been organized only two months prior to this election by Chung Ju-yŏng, won 31 seats. ${ }^{55}$ The voters spoke with an eloquent voice rejecting the machinations of the elite. Later that same year, social justice and reform groups once again organized in participation of the presidential election campaign. In light of a slowing economy and popular rejection of the three-party merger, it seems that in South Korea during the Roh Tae Woo administration, democracy continued its imperfect transitional course, both in spite of, and because of the legacies of an authoritarian past.

54 Bret I. Billet, South Korea at the Crossroads: An Evolving Democracy or Authoritarian Rule Revisited? "Asian Survey", Vol. 30, No. 3, 1990, pp. 300-311, cited in Choong Nam Kim, op.cit., p. 256.

55 John Kie-chiang Oh, op.cit., pp. 118-119, and Carl J. Saxer, op.cit., pp. 103-107. 